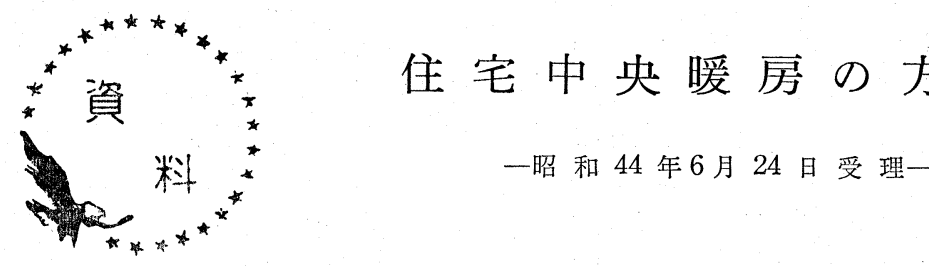

宮内庁今井隆 雄

\section{1. 住宅暖房の分類}

暖房とは寒冷時に人体表面から失われる熱を調節す るために，人体の周囲北熱を供給することである。こ の場合，供給するための 熱を発生する 熱源の 配置計 画, 暖房室に対する熱の供給方法, 熱の利用方法, な どにより暖房の型式を分類することができる。

住宅の中央暖房は, 各個暖房, 中央暖房といら形式 をたどり, 現在はさらに進歩した形式の地域暖房がわ が国に抢いても普及の第一歩を踏み出している。以上
の三つの形式は, 熱源設備の規模と配置方式によつて 分類することができる。（表 1 ，执よび図 3 参照）

1-1 各個暖房

暖房しようとする室ごとに，ストーブなどの熱源を おく方式で, ガス, 灯油, 石炭, 薪などを焚くスト一 ブが利用される。従来もつとも多く利用されてきた方 式であり, 設備費も低く, 簡単に取付け, 取外しが可 能といらような利点はあるが火災, 室内空気の污染, 室内スペースの占有などの問題がある。

表 1 各種暖房方式の設備比較

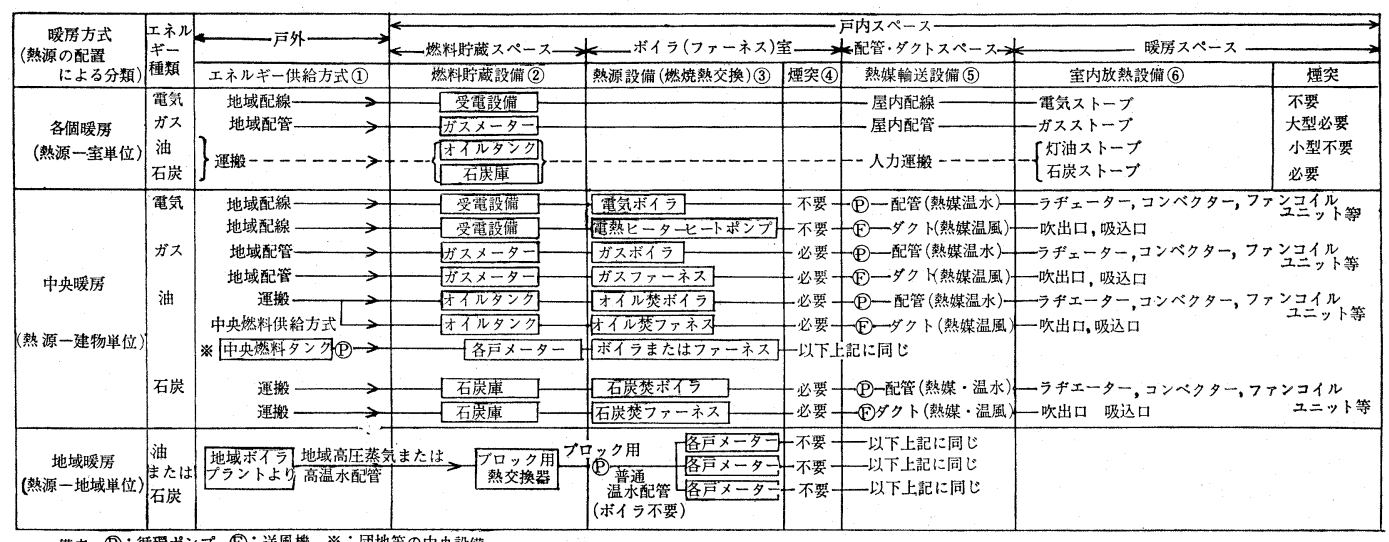

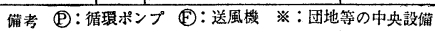

\section{1-2 中央暖房}

セントラルヒーテングと呼ばれ，建物内の中央熱源 設備から，各暖房室へ温水や温風を送り暖房する。 すなわちボイラや温風炉内で然料を燃焼し, その発生 熱量により水や空気を加熱し，これを熱媒として各室 を暖房する。図 1 , 図 2 に温水と温風を熱媒とする, 温水暖房と温風炉暖房の概要を示す。これらの図およ び表 1 から, 中央暖房方式は, 熱源設備, 熱輸送設備 (図中の温水配管, 循環ポンプ, ダクトなど) および ラジエーター, ベースボードヒーター, 吹出口などの
室内放熱設備（ターミナルユニットともいう）から成 り立つていることがわかる。

中央暖房方式は各個暖房方式に比較すると, 設備は 複雑で, 設備費, 運搬費ともに大になる。しかし燃料 の補給や温度調節その他に手段を要しないこと, 全室 を容易に暖房できること，また火災の危険も少なく， ストーブを各室におく場合よりスペースを節約できる など多くの利点がある。中央暖房方式には上記の 2 方 式の他にも種々の方式がある。これについては後で述 ベる。 


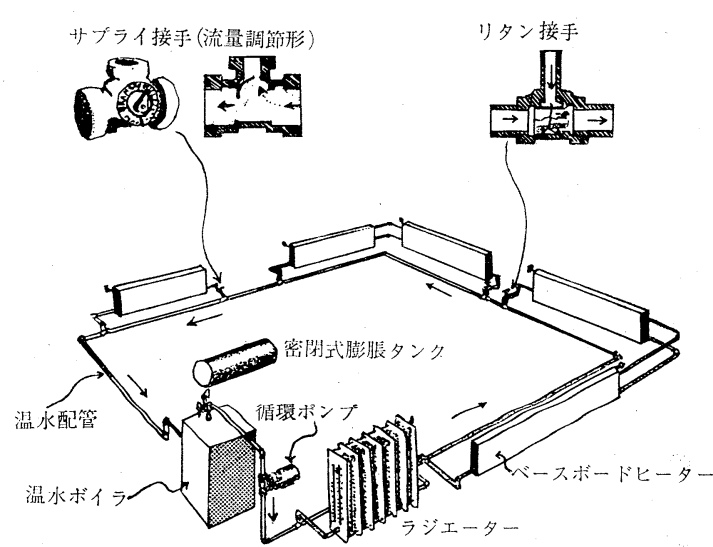

図 1 温水暖房 (熱媒水) 分岐形一管方式と特殊接手

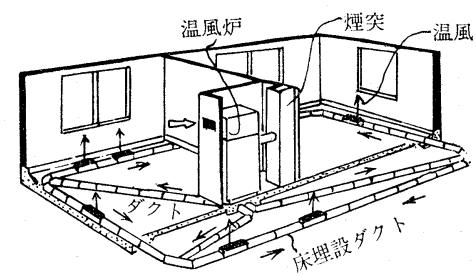

図 2 温風暖房（熱媒空気）ダクトペリ メーター方式（床吹出口）

\section{1-3 地域暖房方式}

地域煖房方式は，中央暖房方式が一つの建物内の熱 源設備の中央化，集中化であるのに対して，さらに集 中化を進め, より広い地域，たとえば大規模の住宅団 地，街区，都市などを対象とする大規模な設備であ る。地域暖房の設備は地域全体の暖房・給湯負荷をま かない得る熱源プラントと, 熱媒の蒸気または高温水 を輸送する配管網, それらの附属設備から成り立つて いる。各建物（住宅む含む）は，暖房用エネルギーを 直接利用できる熱媒の形で受取ることになるので，ボ イラなどの熱源設備, 燃料貯蔵設備などは一切不要に なる。建物内の熱輸送設備, 放熱設備は前述の中央暖 房と同じである。図 3 亿上記の各暖房方式の熱源・配 置の相異を示す。

図 3 の (b), (c) を比較すると, 屋内の配管設備, 放熱器は共通であるから, 両者の経済性を比較するに は, (b) のボイラ設備, 燃料貯蔵設備, それらの所要 スペースの建設費と，(c) の地域配管網と地域ボイラ プラントの各戸負担分を比較すればよい。すなわちこ れらの設備の償却費と運転費・維持費の合計の少ない

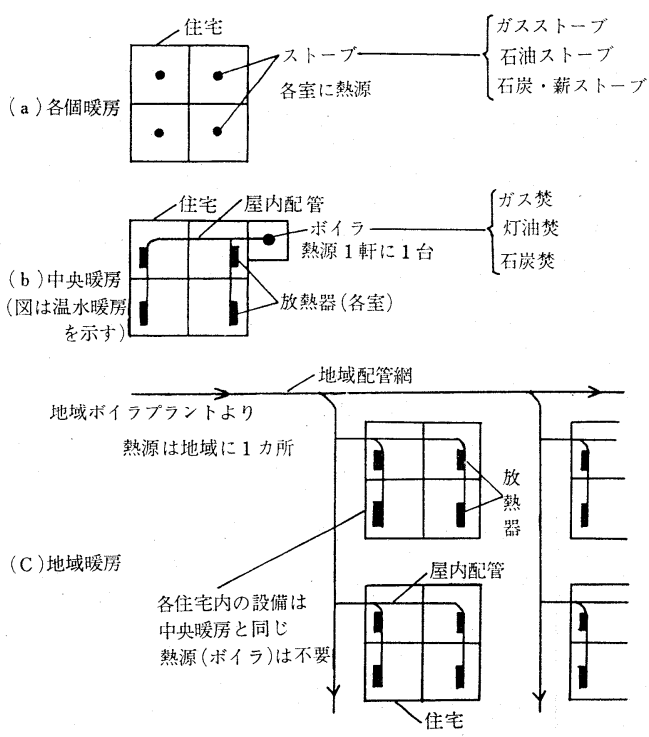

図 3 住宅暖房の諸形式

方が有利といらことになる。

地域暖房は以上のような経済性の問題とは別に，都 市公害の一つである大気污染の防止に有効であること が認められ，注目されている。欧米において広く普及 しているように将来地域暖房設備は, 水道, ガス, 電 気設備などと同様に，都市設備の一つの要素として取 上げられるようになるものと思われる。

わが国の住宅暖房は，従来大部分が各個暖房でまか なわれ，中央暖房は限られたごく一部に過ぎないのが 現状である。しかし最近の所得水準急増の傾向，一般 建築物における空気調和の普及, 膨大な住宅建設量な ぞが中央暖房普及の駆動力となり, 数年後には相当の 普及率になることが予想されている。また，中央暖房 のつぎの段階と考えられる地域暖房が実現されるため には，地域的，経済的，あるいは社会的に多くの制約 がある。わが国でも一部の地方ですでに実現されてい るが，これが普及するためには，まず各戸中央暖房あ るいは中央式給湯が，社会的にも，経済的にも容易に 受け入れられる素地が地域住民の中に育てられなけれ ばならない。そのような意味で, 各戸中央暖房方式の 普及は，地域暖房方式へ移行するために，通らなけれ ばならない一つの過程である。

\section{2. 住宅中央暖房の諸方式}

表 2 亿中央暖房方式の代表的な方式を示す。左端の 欄が一般に呼ばれる名称である。このうちNo.1, No.2, No.3, No.6 は暖房室へ温水を送り暖房する方法, 熱 


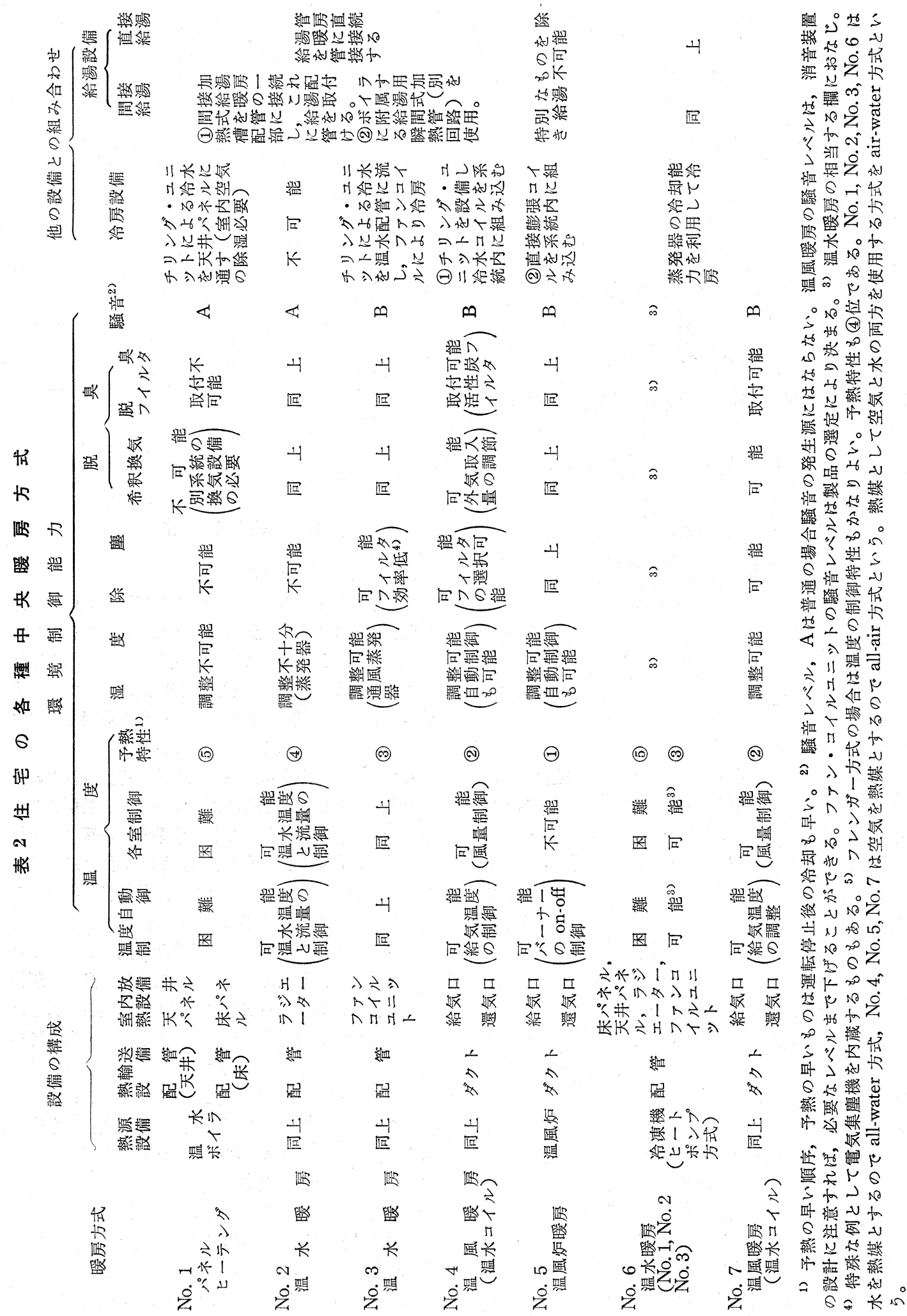


媒が水なので, 水方式または all-water 方式とも呼ば れる。また No.4, No.5, No.7 は温風を室内に送り暖 房する方法で, 熱媒が空気なので, 空気方式または all-air 方式と呼ばれる。熱媒として温水と温風の両方 を送る方式もあるが，これは空気一水方式 (air-water 方式）と呼ばれる。この方式は大きなビルディングな どの暖冷房によく使用される方式であるが，小住宅の 暖房には設備が複雑になり, 設備費も割高になるの で, 使用例は少ない。

表 2 からわかるが, all-air 方式は機械的に室内の換 気を行ならことが可能であり，また空気の除塵や，も し必要ならば活性炭フイルタなどの脱臭装置も取付け ることが可能なので, 室内の空気は, all-water 方式 より清浄にすることができる。しかし all-water 方式 は, 各室に取付けられている放熱器 (パネルラヂェー ター, ファンコイルニニットなど。図 4 参照) の弁を 操作することにより, 各室ごとの使用や温度調整が容 易である。これは然料の節約上大きな効果をもたら す。ただし all-water 方式でも, 床パネルヒーテング （図 5 参照）の場合は，パネルの熱容量が大きいの で, 室の暖房負荷の変化に応じて放熱量を調整し, 室 温を一定に保つことは困難である。図 6 に示す天井パ ネルは, ノールエーのフレンガー氏の発明になるフレ ンガー方式と呼ばれる輻射暖房方式であるが，この方 式は図からわかるように熱容量が少ないので，負荷に 応じて放熱量を変えることができる。各方式のその他 の特性については別項で説明する。

住宅暖房に使用される熱源機器は, 表 2 に示す温水 ボイラ, 温風炉が一般的で, まれにヒートポンプが使 用される。ヒートポンプは 1 機種で暖房と冷房が可能

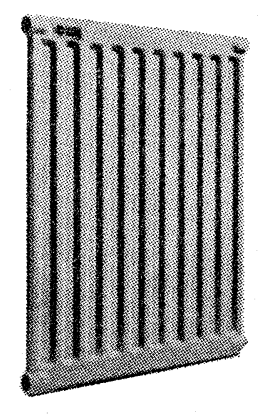

(a)

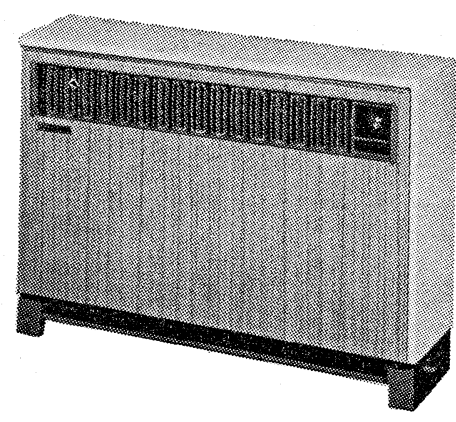

(b) (a) パネルラジェーター

(b) ファンコイルニニット

国 4 放熱器
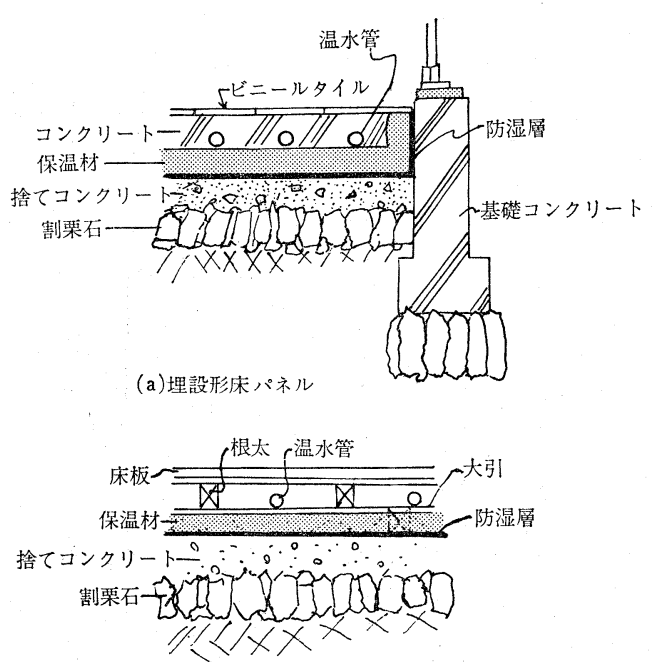

(b)エアスペース内配管麻パネル

図 5 床輻射パネルの構造
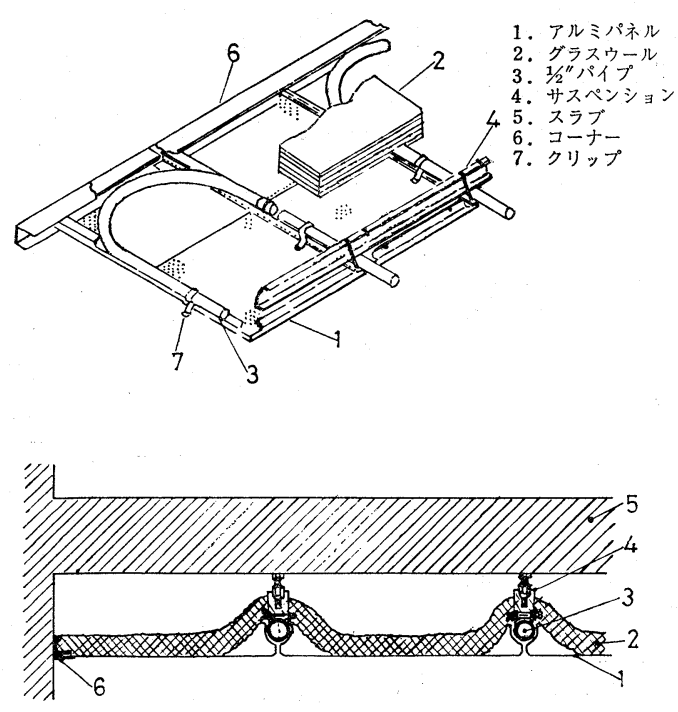

図 6 フレンガー式天井輻射パネル

であるが，暖房のみに限定して比較すると温水ボイラ や温風炉の場合よりかなり割高な設備費になる。図 7 〜 10に温水ボイラの例を示す。図 7 は $250 \times 250$ の寸法 で狭い所に配置できる利点がある。図 8 は貯湯式ボイ ラで給湯負荷あるいは暖房負荷の大きい時に, 出力の 不足分を貯湯量で補うことができる。以上の図 7,8 はいずれも，暖房または給湯どちらかにしか使用でき ない形式で，むし暖房用に使用しながら給湯もしよう とすると, 暖房用の温水で, 間接的に水を加熱して給 


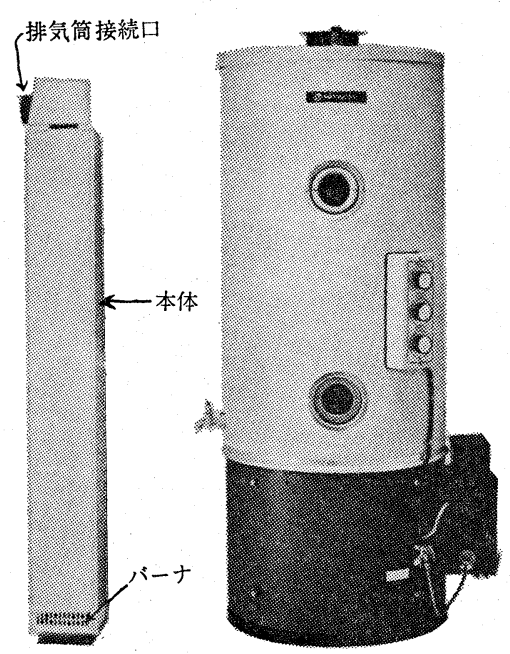

図 7 (左) 灯油焚温水ボイラ（1 回路式）

ガンタイプバーナ付

出力 $20,000 \mathrm{kcal} / \mathrm{hr}$

$250 \times 250 \times 2,000 \mathrm{H}$

図 8 (右) 灯油焚貯湯式温水ボイラ（1回路式）

ポット式バーナー付

出力 $15,000 \mathrm{kcal} / \mathrm{hr}, 5,200 \times 1,360 \mathrm{H}$

貯湯量 $100 l$
湯しなければならない（この方式を間接給湯方式とい ら)。もし暖房用の温水を直接給湯に使用すると給湯 も間接給湯の場合より清浄でなく，その上に暖房用の 配管の腐食を早め，水あかなどのたまりを早くする欠 点がある。この方式を直接給湯式といい，できるだけ 避けるべきである。図 9 のボイラは缶体内に給湯用の 間接加熱コイルをもつているので，給水管をこの管に 接続すると，ただちに湯が得られる。このように暖房 用と給湯用の別回路の加熱装置が，缶体内に組み込ま れているボイラを 2 回路式といら。図10は図 8 のボイ ラ内に組みこまれている給湯加熱用のコイルである。 図7〜9はいずれもオイル焚であるが，ガス焚のボイ ラも使用されている。

図11にオイル焚の温風炉を示す。この方式は燃燒ガ スと空気が直接熱交換する方法であるが，同様に温風 を得るのに図12のように，まず温水をつくり，その温 水により空気を暖める方式むある。表 2 の No. 4 がこ の方式で, 普通の空気調和といわれる方式は, この方 式である。この方式の方が任意の温度の温風をつくる ことができ，暖房の感覚も柔らかい感じになる。設備 費注温風炉暖房が低くなる。

図13はヒートポンプの原理を示すものである。冷凍

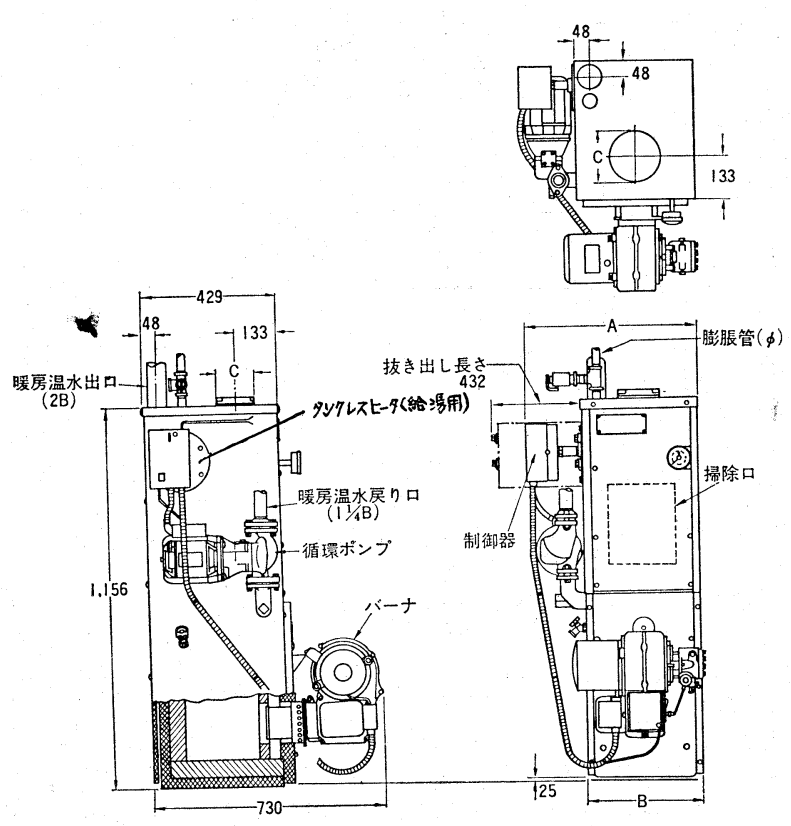

\section{A B C 常用能力}

APT- $95 \quad 546 \quad 362 \quad 152 \quad 24,000 \mathrm{kcal} / \mathrm{hr}$

APT-130 $629445152 \quad 33,000 \quad$ "

APT-165 $711527 \quad 178 \quad 42,000 \quad$ "

図 9 灯油焚鋳鉄製セクショナルボイラ ( 2 回路式)

ガンタイプバーナー付

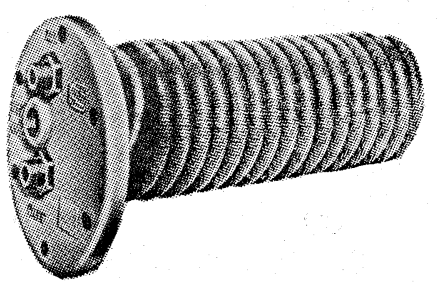

図 10 図 9 の附属タンクレスヒーター 


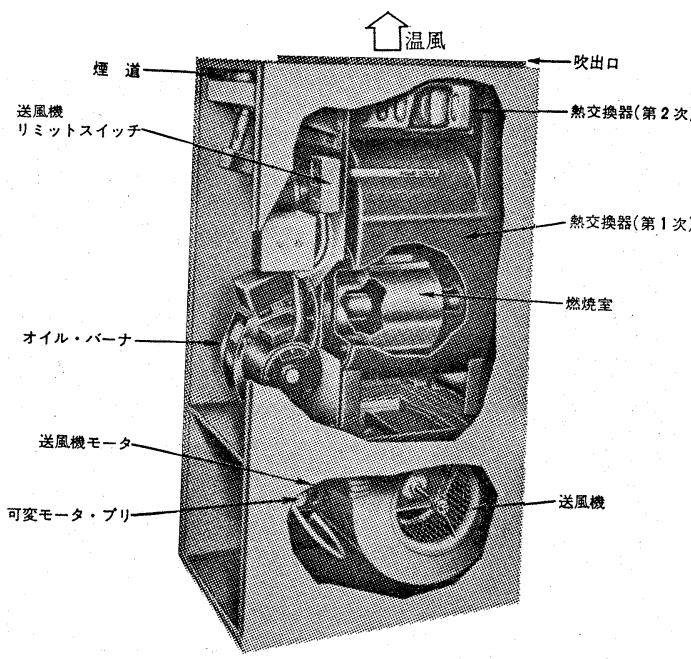

図 11 温風炉

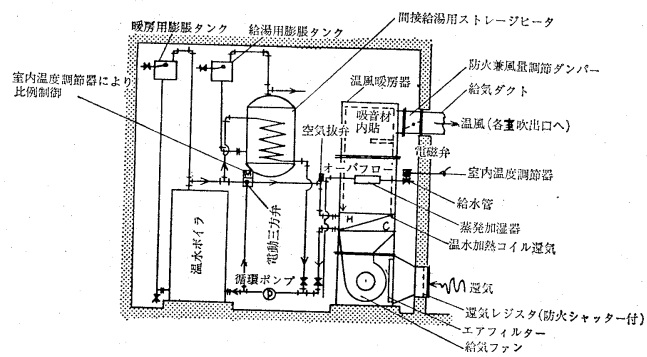

図 12 温水コイルによる温風暖房方式 (間接給湯併用)

機を本来の目的でなく, 加熱の目的で使用する場合 に, 冷凍機をヒートポンプと呼ぶ。眓13において冷媒 は, 配管内を矢印の方向に流れる。蒸発器において液 状の冷媒は, 低圧, 低温で蒸発し, 外部から熱を吸収 する。この部分で冷凍効果が得られる。この低圧のガ ス状冷媒は圧縮器で, 高温・高圧に圧縮され, 凝縮器

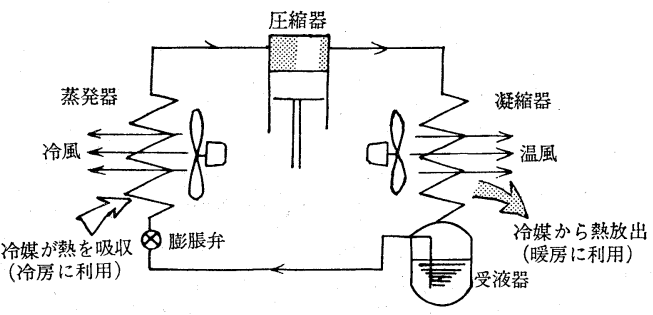

図 13 ヒートポンプの原理

に入る。冷媒は蒸発器で吸収した熱と, 圧縮器で加え られた仕事量に相当する熱を, 凝縮器で放熱し液化す る。この高温の放熱を加熱あるいは暖房に利用する。 熱を低温で吸収し，高温で放熱する機構が，低位の水 を高位にくみ上げるポンプの作用に似ているので，こ の名称で㭔ばれるようになつた。

すなわち冷凍機は，常に冷涷機とヒートポンプの両 機能を合わせ持つているわけである。オフイスビルの 大形冷凍機が，夏季には冷房用に，冬季には暖房用に 使用されている例は珍しくない。最近はウインドー形 やパッケージ形のヒートポンプもかなり普及してきて いる。

\section{3. 暖房と給湯の併用}

暖房と併用する給湯の方式には, 表 3, 図14,15に 示すように, 直接式給湯法と間接式給湯法がある。後 者が優れていることはいらまでもない。

直接式給湯方式は，ボイラ配管内の水が入れかわ るので，管内の腐食，水女かなどの堆積が促進され る。したがつて給湯の水質も悪化し，クレームの原因 になることもある。腐食を防止する目的で, 放熱器, 配管を耐食性の銅管で施工するとしても，好ましい方 法ではない。

給湯には加熱の方式から，瞬閒式と貯湯式がある。

\section{表 3 暖房併用中央給湯方式}

給 湯方式

間接給湯方式 $\left\{\begin{array}{l}\text { 瞬間式 }\left\{\begin{array}{l}\text { ボイラ内熱交換コイル内藏型 } \\ \text { ボイラ外瞬間型熱交換コイル }\end{array}\right. \\ \text { 貯晹式 }\left\{\begin{array}{l}\text { ボイラ内貯湯タンク内蔵型 } \\ \text { ボイラ外貯湯式加熱器 }\end{array}\right.\end{array}\right.$

直接給湯方式 $\left\{\begin{array}{l}\text { 瞬間型（ガス焚に多い）眝晹型ボイラ } \\ \text { 型し給湯に使用する。 }\end{array}\right.$
構

造

暖房と別回路のボイラ内藏熱交換コイルによる給湯 ボイラ外の暖房配管の一部に瞬閒型の熱交換器を設け, これにより別回路の給湯系を加熱する。

ボイラ内に暖房用温水で加熱される別回路の貯湯タン クを設けこれにより給湯する。

ボイラ外の暖房配管の一部に貯湯式熱交換器を設け, これにより別回路の給湯系を加熱する。

ボイラで加熱した温水を暖房用に循環するとともに給 湯にも利用する。 


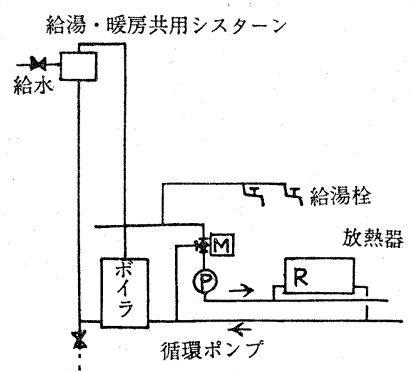

図 14 直接給湯方式

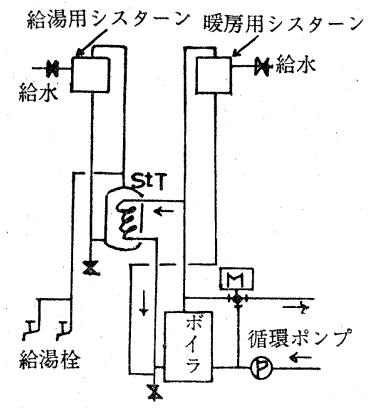

間接給湯槽 (St T) ……重力循環加熱コイル付 単管式給湯配管

（a）間接貯湯式給湯法

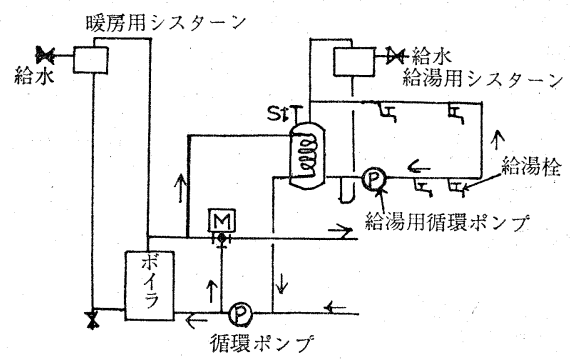

間接給湯槽 $(\mathrm{StT}) \cdot \cdots \cdot . .$. 強制循環加熱コイル付

(b) 間接貯湯式給湯法

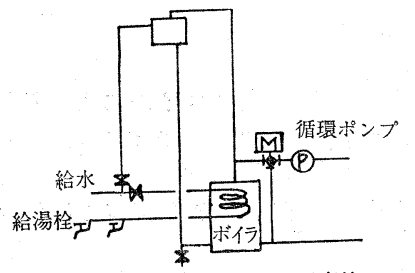

ボイラ内瞬間加熱コイルに水道直結

(c) 間接瞬間式給湯法

図 15 間接給湯方式
瞬間式は給湯負荷が直接作用するので，ボイラ容量が 大きくなる傾向がある。たとえば $5^{\circ} \mathrm{C}$ の水を $50^{\circ} \mathrm{C}$ に加 熱し， 20 分間で $150 l$ 給湯 (浴槽)するものとすると, $150 \times(50-5) \times \frac{60}{20}=20,250 \mathrm{kcal} / \mathrm{hr}$ に達する。これに 暖房負荷を加えなければならないので，入浴給湯時の 暖房負荷を低く見積つても, 最低 $25,000 \mathrm{kcal} / \mathrm{hr}$ のボ イラが必要になる。これに比較し貯湯式の場合は，入 浴給湯時の前記瞬間負荷を, 貯湯量でまかならことに すると，貯湯量が多ければボイラに作用する負荷は小 さくてすむ。150 200l 位の貯湯槽が市販されている が、これをボイラと組み合わせて使用することによ り，合理的なボイラ容量を選ぶことができる。

\section{4. 暖房と冷房の併用}

中央式暖房を計画する場合に，将来中央式冷房を可 能にするには, 表 2 のうちの No.3, No.4, No.5, No. 7 および No.6 の5ちの室内放熱器にファンコイルユ ニットを使用する方式をえらんでおかなければならな い。表 4 亿前記方式を冷房併用方式にするための方法 を示す。

\section{5. 温 水 暖 房}

温水暖房設備は表 $1 ， 2$ に示すように, 熱源設備, 熱輸送設備, 室内放熱設備（ターミナルニニット）氻 ら成り立つている。熱源設備のらちのボイラは, 先 の説明が全部温水ボイラであつたよらに，蒸気ボイラ はほとんど使用されない。その理由は負荷の変動に対 して, 蒸気暖房では放熱量の調節がしにくいこと, ま たトラップ，給水ポンプ，その他保守に 手数がかか る,「ボイラおよび圧力容器安全規則」の適用を受け ない限界の容量が，蒸気ボイラの方が温水より小くな る,などである。たとえば設置認可，ボイラ室に関す る規則，就業制限などは，蒸気ボイラでは，圧力 $1 \mathrm{~kg}$ $/ \mathrm{cm}^{2}$ 以下，伝熱面積 $0.5 \mathrm{~m}^{2}$ 以下，胴内径 $200 \mathrm{~mm}$ 以 下，長さ $400 \mathrm{~mm}$ 以下であれば，その適用を受けない。 温水ボイラでは, 水頭圧 $10 \mathrm{~m}$ 以下, 伝熱面積 $4 \mathrm{~m}^{2}$ 以 下であればよい。したがつて伝熱面積 $1 \mathrm{~m}^{2}$ 当たり $12,000 \sim 35,000 \mathrm{kcal} / \mathrm{hr}$ の出力を有する温水ボイラの 方が，容量的に大きなボイラを規制を受けずに使用で きる。

温水暖房の熱輸送設備は, 配管とポンプであるが, 配管方式の選定と, ポンプの取付位置の決定には注意 を要する。温水暖房の配管方式に重力循環式と強制循 環式がある。前者は温水の往きと還りの温度差にもと うくく水の密度差を駆動力とするものであるから, ボイ ラと放熱器関のある程度の高さの差が必要である。最 
表 4 中央暖房方式で冷房を併用する方法

\begin{tabular}{|c|c|}
\hline 暖房方式 & 熱源設備 \\
\hline
\end{tabular}

(All-Water 方式) $\begin{cases}\text { 温水ボイラ } & \text { ファンコイルニニット } \\ \text { ヒートポンプ ファンニイルュニット }\end{cases}$

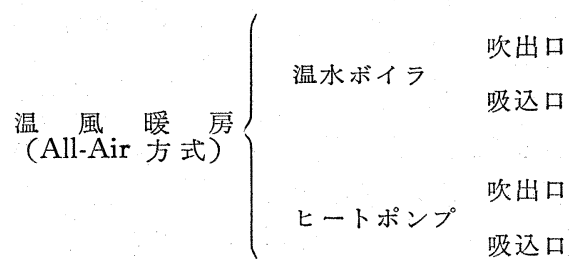

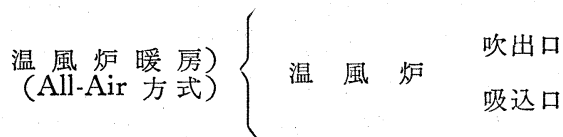

泠房併用の方法備考

泠水装置を温水配管系につなぎ 込む

夏季は冷凍機として運転し冷水 をつくり, 配管系に循環させ る。(*印の方法)

○冷水装置取付け冷水コイルを 図 12 の加熱コイルの上に組み 込む。

○直接膨張形コイルを組み込 む。

冷媒配管を切換えて加熱コイル

(凝縮器) を, 冷却コイル（蒸 発器) にして空気を冷却する。 *印の方法も㐫。

直接膨張形冷却コイルを取付け 図18のように切換えて運転す る。

(温風炉の温風出口に冷却コイ ルを取付けることもある)

\section{図 12 参照}

図 16 参照

図 17 参照

図 18 参照

*冷媒サイクルはそのままにしておいて, 水配管側を夏季は蒸発器に通し冷水をつくり冬季は㠜縮器に通して 温水をつくる。

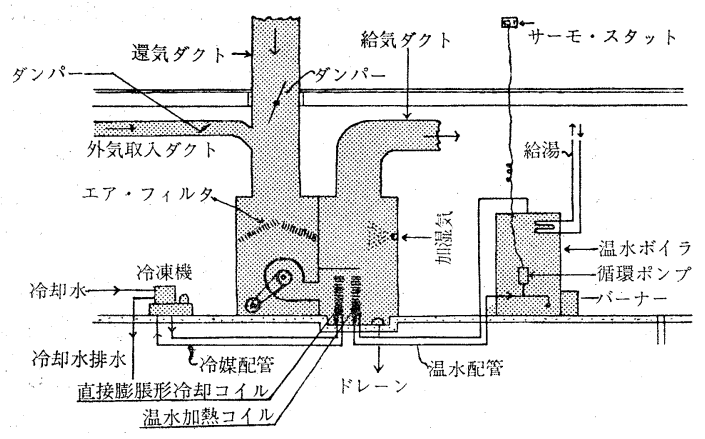

図 16 温風暖房 (加熱コイル方式) と冷谏機（直 接膨張形冷却コイル）の組合わせ

(a)

冬季暖房サイクル

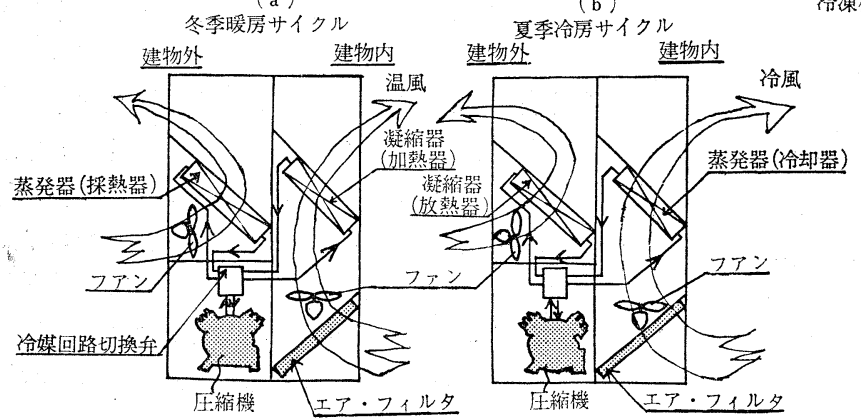

図 17 ヒートポンプの冬季暖房サイクルと夏季冷暖サイクル

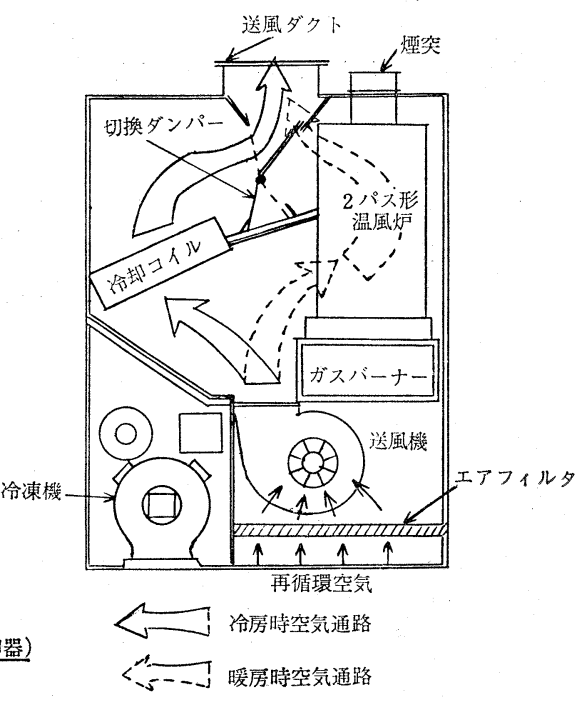

図 18 温風炉と冷㣀機組み合わせ例 
近の小住宅では，いわゆる同階暖房といわれる方式 で, ボイラと放熱器が同一フロアにあるような設備が 多いので，この方式では循環力が得られず, 重力式は ほとんど使用されない。

強制式は 50 200W の温水循環 ポンプを使用する もので, 重力式に比較して配管径も小さく, 温水の配 分調整も自由にできるので, 現在の小住宅の中央暖房 は，この方式に限られていると言つても過言ではな い。
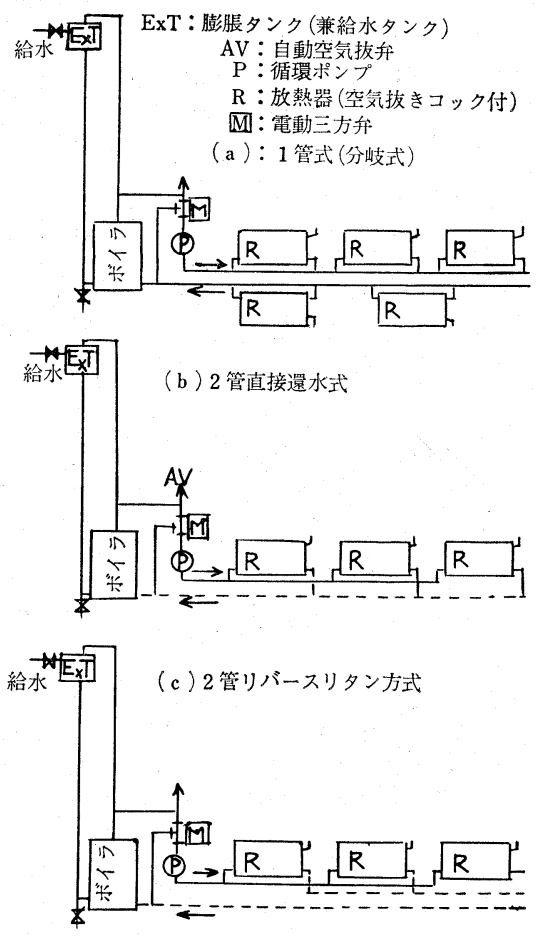

図 19 温水暖房の配管方式

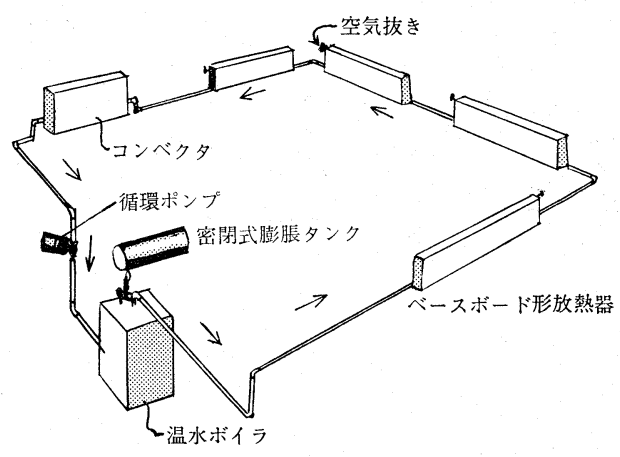

図 20 ループ形一管方式の温水暖房
また配管方式には，往管と還り管を別々に配管する 2 管式 (図 19 参照) と，1 本の管をループ式に配管 し，その管から放熱器に至る管を分岐する分岐形一管 方式（図 1 および図 19 の (a) 参照) と，ループ配管 に直接放熱器を接続するループ形一管方式（図 20 参 照）がある。一管式は放熱器に流入する温水温度が, 後へ行くほど下がるので，大規模な設備には使用でき ない。しかし小規模な場合には配管が簡単なので，設 備費安くなる。

配管内の温水の膨張収縮を吸収するために，膨張夕 ンクを取付ける。最上部の放熱器から膨張タンクまで の必要高さは, ポンプのヘッドとも関連があり，でき るだけ大きい方が望ましいが平屋の場合には限度があ る。また保守の便宜を考えるとボイラ室内にあつた方 が都合がよい。そのような条件を満たすものとして図 1 あるいは図 20 に示すような密閉式膨張タンクがあ る。将来ボイラとセットにした形で, ボイラ室内に設 けられる例が多くなるものと思われる。

住宅用循環ポンプのヘッドはなるべく小さい方がよ い。小住宅の場合は $2 \sim 4 \mathrm{~m}$ 位に選び，管内の水速は $0.7 \sim 0.8 \mathrm{~m} / \mathrm{sec}$ 以下位におさえた方がよい。またポン プの取付位置であるが，配管系の下部に取付け，膨張 タンクが低い場合は, 図19のように，ポンプのサクシ ヨン側に膨張タンクがくるようにポンプを取付けると よい。ポンプのヘッドを過大に選ぶと，管内流速が過 大になり，騒音を発生することがある。またポンプの 取付けの際その支持方法が悪いと，騒音が配管に伝わ ることがあるから注意を要する。ポンプのサクション 側と吐出側の間を小口径の管で結びバルブを取付けて おくと，ポンプの水量調整に便利である。住宅暖房専 用の小型ポンプの中にはこのようなバイパス装置をポ ンプ本体の中に有するものもある。

温水暖房のターミナルユニットには, 図 4 , 図 5 に 示すような各種の放熱器がある。送風機とフィン付の 放熱管を有するファンコイルニニットは，当然小型で 放熱能力が大きく，面積の小さなわが国の住宅暖房 には多く利用されている。またこの方式は室内空気を 強制的に循環するので，室内温度分布をよくする作用 もある。パネルラヂエータやコンベクタなどは自然対 流なので，放熱量当たりの大きさは，ファンコイル ユニットより大きくなる。図 21 に各種の放熱器の $1,000 \mathrm{kcal} / \mathrm{hr}$ 当たりの占有面積を示す。また図 22 は 各種の放熱器による室内温度分布の一般的特性を比較 したものである。もちろん個々の室の温度分布は，そ の室の暖房負荷の特性や，放熱器の配置によつて異な 


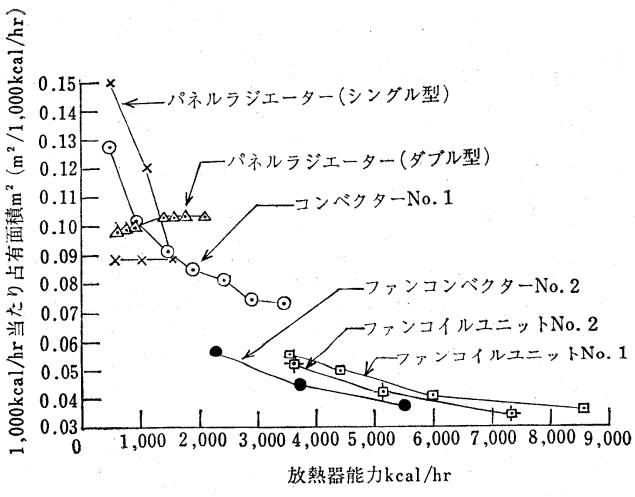

図 21 各種放熱器の放熱量当たりの占有面積

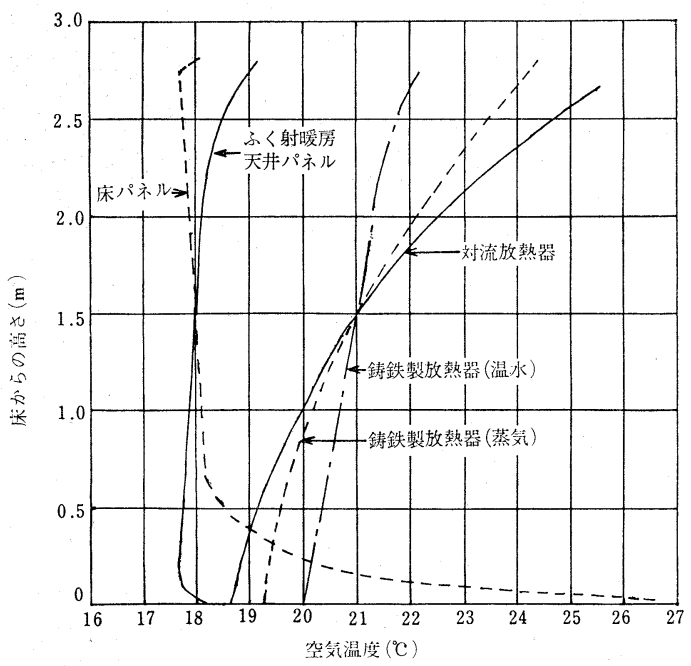

図 22 各種暖房方式による垂直温度分布の比較

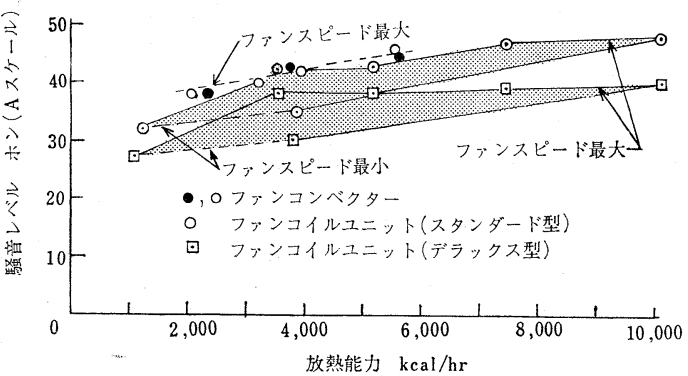

図 23 ファンコイルユニット, ファンコンベク ターの駆音レベル

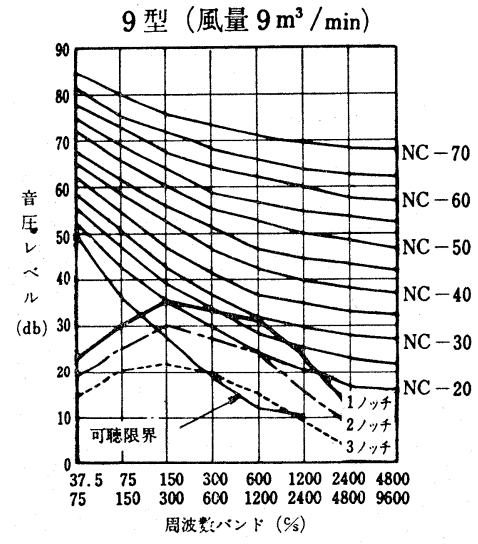

図 24 ファンコイルユニットの駆音特性の例

る。一般的に言えることは，放熱面温度があまり高く ない放熱器を多く設ける方が室内の温度分布はよくな る。また放熱器は空下などの暖房負荷の大きい部分に 取付けると室内の温度分布をよくする効果がある。

放熱器が発生する騷音は，低いことが望ましい。住 宅内の許容騒音レベルの 標準としては，35 40 ホン (Aスケール), または許容 $\mathrm{NC}$ 值として 25 30があ たえられている。寝室などではさらに低い值が要求さ れることがある。図23と図24はともにメーカーカタロ グからとつた值である。この図からもあきらかである が，寝室などとくに静肃を要する場所のファンコイル ユニットは, ファンスピードの最大でない点の放熱量 によつて選定しておけば，図のように騒音レベルを 5 〜10ホン下げることができるわけである。

\section{6. 温 風 暖 房}

温風暖房設備は空気を熱媒とする暖房設備で, Allair 方式の暖房設備と考えると, 加熱コイルによる温 風暖房 (図12参照) と, 温風炉 (図11) 参照による温 風炉暖房の両方が含まれる。これらの熱源設備と, 送 風機，空気ダクトからなる熱(媒)輸送設備，および室 内の吹出口，吸込口（還気口）から構成されている。 加熱コイルによる温風暖房は, 温水ボイラ, 蒸気ボイ ラによる温水や蒸気を加熱コイルに通して空気を加熱 する方法で, 空調方式と呼ばれることもある。図 $12 に$ は間接給湯設備を含む方式で, 機器の配列を示した ものである。表 5 は両者の特性を比較したものであ る。

温風暖房方式は, 外気の取入れによる換気, エアフ イルタによる除塺ができるので, 温水暖房の場合よ 
り，室内空気条件を良好に保つことができる。温水暖 房の場合も加湿が必要になることがあるが，温風暖房 ではとくに加湿に注意しないと，乾燥しすぎることが 多い。熱源装置の容量には，積極的な換気を行なうこ とが条件になつている場合は，外気負荷を加えなけれ ばならない。一般に小住宅の温風暖房では, 居室の人 数も少なく, 空気の污染も低いので, 通常の運転時は 積極的な換気を行なわず，自然換気に期待することが 多い。しかし旡房排気ファンの排気量に相当する外気 負荷を見込んでおくこともある。
住宅の暖房負荷は，オフイスビルの暖房負荷のよう に画一的なものでなく，各家庭の生活習慣にもとづく 暖房スケジュールにより，広い幅をもつものであるか ら, 機器容量を決める場合注，施主々充分な打合わせ を行ない，いたずらに過大容量の設備をしないように 注意しなければならない。過大な設備は，大は小を兼 ねるといらことではなく，稼動率が下がり，それに伴 つて熱効率も低下し，機能的にも経済的にも損失が大 きいものである。

表 6 は住宅用小型温風炉の諸元である。空調方式の

\section{表 5 温風炉暖房と温風暖房（空調方式）の比較}

\section{方 式 熱源関係機器 \\ 温風炉暖房 $\left\{\begin{array}{c}\text { 温風炉 } \\ \left(\begin{array}{l}\text { 含送風, エ } \\ \text { アフルタ }\end{array}\right)\end{array}\right.$ \\ 温風暖房 $\left\{\begin{array}{l}\text { ボイラ, 温水循環 } \\ \text { ポンプ, 空気加熱 } \\ \text { コイル, 同用ケー } \\ \text { シング, 膨張タン } \\ \text { ク, 温水, 給水, } \\ \text { 排水配管工事 }\end{array}\right.$ \\ 備 考 $\left\{\begin{array}{l}\text { 給油, 電源関係工 } \\ \text { 事は共通 }\end{array}\right.$}

熱媒関係機器

ダクト, 吹出

口, 還気口,

ダンパー, 吹 $\sim 50^{\circ} \mathrm{C}$ )

同上

送風機，エア

・フイルタ,

$\left(10 \sim 25^{\circ} \mathrm{C}\right)$

室内温度分布

は温風暖房の

方がよい。ダ

クトは温風炉 方式が小。
温度 制 御

オン・オフ制御 不可能可 能

三方弁による比

例制御

図 12 参照

可 能

冷宛

その他

温度制御は温風 方式の方が優れ
温水暖房に比 較し，凍結漏 水の心配な ᄂ。 ウォーム・ア ツプが早い。

\section{表 6 住宅用小型温風炉の諸元, 吹出温度差}

\begin{tabular}{|c|c|c|c|c|c|}
\hline 項 & A & $\mathrm{B}$ & $\mathrm{C}$ & $\mathrm{D}$ & $E^{2)}$ \\
\hline 格 放 熱 量 & 18,000 & 22,000 & 25,200 & 30,200 & 13,150 \\
\hline 燒 方 & $\begin{array}{l}\text { ポット式強制 } \\
\text { 通風 }\end{array}$ & $\begin{array}{l}\text { ガンタイプ } \\
\text { バーナ }\end{array}$ & $\begin{array}{l}\text { ガンタイプ } \\
\text { バーナ }\end{array}$ & $\begin{array}{l}\text { ガンタイプ } \\
\text { バーナ }\end{array}$ & $\begin{array}{l}\text { ガンタイプ } \\
\text { バーナ }\end{array}$ \\
\hline 焼 用 電 動 機 & $23 \mathrm{~W}(100 \mathrm{~V})$ & 一 & - & - & - \\
\hline 風 & $1,200 \mathrm{~m}^{3} / \mathrm{hr}$ & $1,900 \mathrm{~m}^{3} / \mathrm{hr}$ & $2,040 \mathrm{~m}^{3} / \mathrm{hr}$ & $2,260 \mathrm{~m}^{3} / \mathrm{hr}$ & $1,050 \mathrm{~m}^{3} / \mathrm{hr}$ \\
\hline 効 静 & $6 \mathrm{mmAq}$ & - & $10 \mathrm{mmAq}$ & $5 \mathrm{mmAq}$ & $3 \mathrm{mmAq}$ \\
\hline $\begin{array}{c}\text { 用 用 電 動 機 } \\
\text { 出 温 度 差 }{ }^{1)}\end{array}$ & $\begin{array}{c}0.25 \mathrm{~kW}(100 \mathrm{~V}) \\
\quad \doteqdot 50^{\circ} \mathrm{C}\end{array}$ & $\begin{array}{c}0.25 \mathrm{~kW}(100 \mathrm{~V}) \\
\doteqdot 38^{\circ} \mathrm{C}\end{array}$ & $\begin{array}{c}0.25 \mathrm{~kW}(100 \mathrm{~V}) \\
\doteqdot 39^{\circ} \mathrm{C}\end{array}$ & $\begin{array}{c}0.25 \mathrm{~kW}(100 \mathrm{~V}) \\
\doteqdot 44^{\circ} \mathrm{C}\end{array}$ & $\begin{array}{c}0.075 \mathrm{~W}(100 \mathrm{~V}) \\
\doteqdot 41^{\circ} \mathrm{C}\end{array}$ \\
\hline
\end{tabular}

1) 加湿量を風量 $1 \mathrm{~m}^{3}$ 当たり $1 \mathrm{~g}$ とした場合，2）ガス焚ファーネス

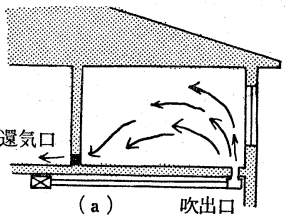

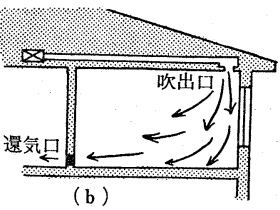

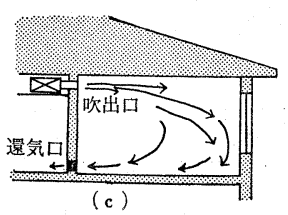

図 25 吹出口配置の方式 
温風暖房設備は, 暖房負荷に応じて, 図12に示す温水 加熱コイルの大きさや列数を計算により求めて購入す る。温風炉暖房は表 5 亿示すように, 温風炉に電源と 給油管（給油タンクを自納しているものもある）を接 続すると，直ちに機能を発揮できるように工事が簡単 なことが大きな利点である。また寒冷地でも，運転休 止中に温水暖房のように凍結の心配がないことも取扱 い上有利である。しかし表 6 に示されているように, 吹出温度差が高いといら久点がある。したがって吹出 口，還気口の配置が悪いと，他の方式以上に温度分布 が悪くなりやすい。図25はダクト，吹出口，還気口の 配置を示す図であるが，室内温度分布の上からは， （a）が最良，以下 (b)，(c) の順序である。(c) の方 式は空面から降下するコールドドラフト (冷気流) に より床面温度が下がり快適性を損致る。とくに外気温 の低い寒冷地ではその影響が強いので，(a) または （b）にすることが望ましい。

温風暖房の騒音源は, 送風機の発生騷音がダクトを 通して室内に入る場合と, ダクト内あるいは吹出口部 における風速が過大で気流音が発生する場合の両方が ある。小住宅用の温風暖房では, 使用する送風機の所 要出力は $1 / 3 \sim 1 / 2 \mathrm{HP}$ の小形のものが多く, したが つて音響出力も小さい。普通の住宅設備では, ダクト 系に消音チャンバ 1 個あるいはこれにもう 1 個消音エ ルボを追加設備すれば, 室内騒音レベルを標準の $\mathrm{A}$ ス ケール35 40ホンにすることが可能である。

\section{7. ヒートポンプ}

ヒートポンプの概要については 2 章に説明した。ヒ ートポンプは要するに冷凍機であるから，温水ボイラ や温風炉などに比較して設備費は高い。しかし前述し たように中央冷房もする場合は，ボイラが不要なの で, 暖房・冷房の全設備を比較すると, ボイラが不要 になり有利である。

ヒートポンプにより暖房する場合, もう一つ問題に なることは, 電力を使用するので, 燃料を使用する他 の方式と比較してエネルギーコストが高くならない か，どうかといらことである。このエネルギーコス トを検討するときの指標となるものに，ヒートポンプ の成績係数というものがある。ヒートポンプの成績係 数を $\varepsilon_{h}$ とすると次式で表わされる。

\section{$\varepsilon_{h}=\frac{\text { 凝縮器で得られる暖房用熱量 } \mathrm{kcal} / \mathrm{hr}}{\text { 圧縮機運転の所要電力の熱量換算値 } \mathrm{kcal} / \mathrm{hr}}$}

図20 は R-12 を冷媒とする実際の冷媒機で得られ る成績係数を示したものである。この図からわかるこ
とであるが，高い成績倸数で蓮転するには，蒸発温度 が高く, 凝縮温度が低いほどよい。冷媒が周囲から効 率よく熱を吸収して蒝発するには，蒸発温度より 7 $10^{\circ} \mathrm{C}$ 温度の高い熱源が必要である。蒸発温度を $7^{\circ} \mathrm{C}$ と すると周囲に $15 \sim 16^{\circ} \mathrm{C}$ の温度をもつ熱源が必要であ る。熱を吸収する熱源として, 年間を通じて温度がほ ぼ一定の井水がもつとも適した性質をもつている。そ の他われわれの周囲にある豊富な熱源として, 大気, 河川水，海水などがあるが，これらはいずれも暖房負 荷が最大になる笽寒季に温度がもつとも低いといら久 点がある。ことに大気を熱源とする空気熱源方式は, この欠点が顕著である。図27は空気対空気式のウィン ドー形ヒートポンプの暖房特性である。空気対空気と

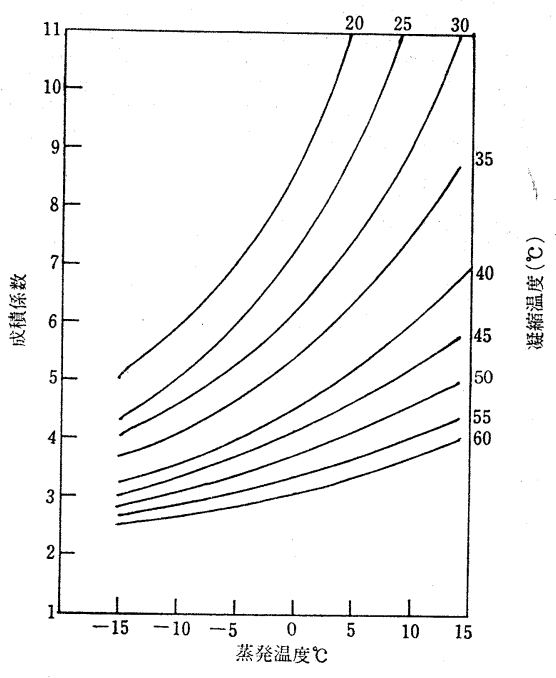

図 26 R-12 ヒートポンプの実際の成績係数

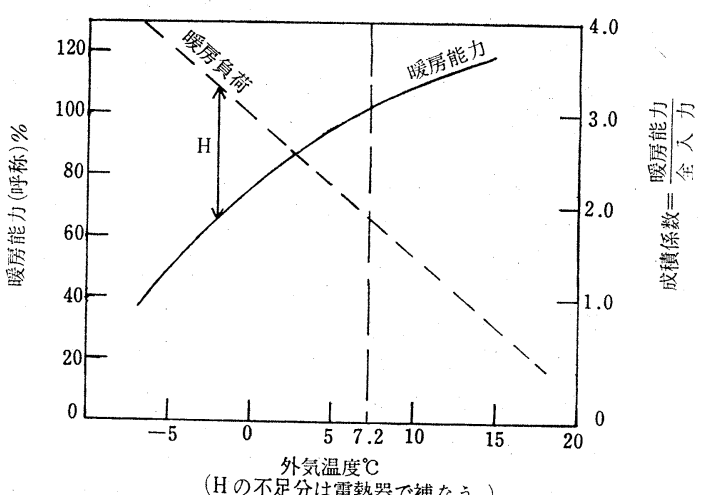

図 27 ウィンドー型ヒートポンプの暖房特性 (空気熱源) 
表 7 . 各 種 方 式 $の$ 燃 料 費

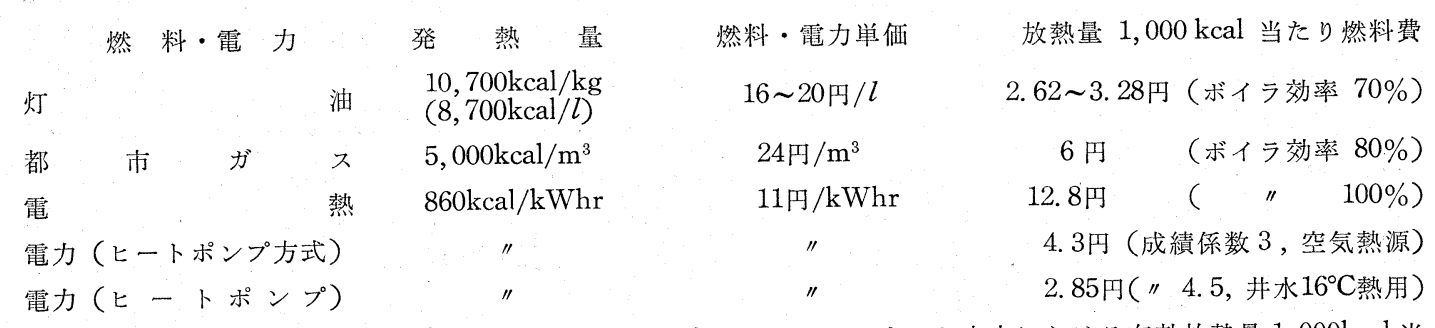

注）上記の放熱量 $1,000 \mathrm{kcal} / \mathrm{hr}$ 中に配管損失分が含まれているとすると室内における有効放熱量 $1,000 \mathrm{kcal}$ 当 たりの然料費は，同闌の值に $\frac{1}{(1-\alpha)}$ を乗ずればよい。

は，外気を熱源として蒸発気で熱を吸収し，凝縮器で 温風をつくり暖房する方式をいら。すなわち熱の吸収 (蒸発器) も放熱 (凝縮器) の両作用とも空気を熱媒 として使用する方式である。同図によると外気温度約 $7.2^{\circ} \mathrm{C}$ の点で成績係数が約 3 になつている。外気温度 が低下するにしたがい，暖房能力，成績係数とも低下 し, $0^{\circ} \mathrm{C}$ において成績係数は約 2 , 暖房能力も約 $75 \%$ に低下する。暖房負荷と暖房能力の差Hは, 電熱ヒ一 ターその他の補助熱源で補わなければならないことに なる。

表 7 はヒートポンプの成績係数により, 暖房用熱量
のコストが変化することを示したものである。これ によると成績係数が 4 以上になると灯油然料の温水ボ イラに匹敵することがわかる。ヒートポンプが他の熱 源設備と有效放熱量当たりのコストで競合できるの は，熱源として井水が豊富に利用できることが条件に なるといつてもよい。

以上小住宅の中央暖房設備として, 一般に利用され ている方式について簡単に説明した。これらの各方式 の設備費・運転費などについては機会があれば述べる ことにしたい。

\title{
Central Space Heating Systems in Residences
}

\author{
by Takao Imai
}

(Imperial Household Agency)

SYNOPSIS :-Recent pervation of the residential central space heating is remarkable. This is supported by remarkable incleasing of national income and recognition about improvement of living environments which are compared with air conditioned environments in general office buildings.

At the begining, this paper explains on the residential central space heating as compared with inddividual space heating and district heating. See Table 1 and Fig. 3 .

The residential central heating systems are classified into three groups by heat medium for space heating. Those are all-air system (warm air heating system), all-water system (hot water heating system) and air-water system (fan coil unit and supplementary hot air). A air-water system is too complicate to residence use, so it is scarcely used.

All the system has a boiler or a hot air furnace or a heat pump as heat producing equipment. A boiler and hot air furnace is selected frequently, but a heat pump system is scarcely selected. Because initial cost of a heat pump system for heating only is comparatively high-priced, but for yearound air conditioning competes with other systems 
in initjal cost.

Moreover this paper shows, there are some problems awaiting solution about system planning and designing. For instance one of the problems is usage of a domestic hot water supply system or a summer cooling system together with a heating system itself. 